\title{
SIX DIMENSION STRATEGY AS A BASIS OF BANKING STANDARD CONTRACT
}

\author{
Wulanmas Frederik ${ }^{1}$
}

\begin{abstract}
Indonesia banking based on Article 4 of Act No.10, 1998, aims at supporting the implementation of national development in order to improve equity, economic growth and national stability in the direction of improving people's welfare. Therefore, to show how important is banking role in supporting the implementation of development, the 6 (six) Strategic Dimensions as the foundation of Banking Standards Contract are: (1). Prudent Banking Supervision and Good Corporate Governance (GCG) in banking activities, (2). Refunctionalization the principle of Contract Law in Banking Standards Contract, (3). Ethics Value in Business, (4). The Act No. 8, 1999 on Consumer Protection, (5). Enforcement of Human Rights Principles in banking activities, (6). Abuse of Circumstances implementations (Misbruik van Omstandigheden) in banking Contract. Based on the 6 (six) Strategic Dimension as the foundation of Banking Standard Contract, it will undoubtedly create justice, equity and assurance of the rights and obligations of the parties framed in the contractual and law bonds.
\end{abstract}

\section{Keywords: Banking, Contract, Dimension, Foundation}

\section{Introduction}

Economic conditions frequently used as a source of consideration in putting progress strata of a state turn into disarray because of the swift current of change sweeping and striking the structure of Indonesian life so that the entire aspects of social orders almost shift to find a new substance according to the challenges and opportunities ahead. It is unknown how long banking community is beaten by the boredom of waiting period for expecting the reality of improved concept of standard contract as the basic framework used as a frame in a business relationship between Debtor and Bank as a creditor, so the assurance of rights and obligations of parties become clear and detailed.

The discourse to create opportunities of justice and balance for parties banking standards Contract is still far from expectations. As we know, that the cause of economic structure disruption in banking standard contract is the violation of law arbitrarily by market participants having dominant position so that debtor must inevitably be run over by monopolistic market. Law provisions, as the runway of economic activity, are tricked without hesitation, and it is worse that the efforts of law enforcement in this country are just as implemented as the embodiment of responsive law. The discourse of Banking

${ }^{1}$ Lecturer Faculty of Law, Sam Ratulangi University, Manado. Obtained Bachelor of Law (S.H.) from Sam Ratulangi University (1988), Master of Law (MH) from Sam Ratulangi University (2001), and a Doctor of Law (Dr) from Diponegoro University, Semarang (2010). 
Consumer Protection as outlined in the sixth pillar of the Indonesian Banking Architecture (API) program is almost like a row of sentences stuck in the frame of the Indonesian Banking Architecture for what becomes the goal of facilitating consumer banking aspiration is far from expectations.

As the information, basically, banking Standard Contract is a standard contract with the forms and contents have been prepared in advance by bank or creditor, and then presented to debtor. Theoretically, the position of debtors and bank as creditor should be balanced, but in practice or empirical level it was not as expected. This is due to banking standards Contract is a contract that the concept has been prepared or has been made in advance by Bank as a creditor including general rules or special requirements whereas debtors only learn and understand it well, without getting any chance at all to sit together in determining the contents of the contract as a realization of the right of debtor. It can be seen in the Contract that debtor is only in a position to accept or reject without any possibility to negotiate or bargain.

Consciously or not, the inclusion of the terms in banking standard contract seems to be favorable to bank that has prepared in advance of its making and it is certainly highly harmful to debtor. These conditions make the position of Bank as creditor is superior compared to the position of debtor so that the debtor position is weaker and lower than bank. Therefore, it is not surprising that these conditions have created opportunities of imbalance between bank as creditor and debtor.

Through the application of 6 (six) Strategic Dimension as the foundation of Banking Standards Contract;

1. Prudent Banking Supervision and Good Corporate Governance (GCG) in banking activities.

2. Refunctionalization the principle of Contract Law in Banking Standards Contract.

3. Ethics Value in Business.

4. The Act No. 8, 1999 on Consumer Protection.

5. Enforcement of Human Rights Principles in banking activities.

6. Abuse of Circumstances implementations (Misbruik van Omstandigheden) in banking Contract, it will be possible to create a sense of justice, balance and assurance of the rights and obligations of the parties framed in contractual and law bonds and signs laws.

\section{Analysis}

Article 33 of Indonesian Constitution (UUD 1945) states that the national economy is held based on economic democracy with the principles of togetherness, efficiency, justice, continuous, environmental friendliness, independence, and balancing economic progress and national unity. It means that according to the concept of economic democracy, prosperity is for all Indonesian people for the purpose of national development is to realize a just and prosperous society, even in material and spiritual in the era of economic democracy based on Pancasila and the Constitution of 1945.

Departing from the implementation of national development objectives, Article 4 of Act No.10, 1998 on Banking states that: "Bank Indonesia aims to support the implementation of national development in order to improve equity, economic growth and national stability in the direction of improving the 
welfare of the people". It means that the important and strategic role of banking institutions is one of the main pillars for economic development and as an agent of development in supporting the implementation of national development, so that in facing national economic development which is always fast moving, competitive, integrated, with the increasingly complex challenges, it requires a national banking institution that is able to drive the national economy in supporting the implementation of national development.

Then to show the role of banking in developing Contract Law principles, The 6 (six) Strategic Dimension as the foundation of Banking Standards Contract are:

\section{A. Prudent Banking Supervision and Good Coorporate Governance (GCG) in Banking Activities}

The term corporate goverance was introduced by Cadbury Committee in 1992 in their report, known as Cadburry Report. The report is seen as a turning point that determines the practice of Corporate Gorvernance worldwide. ${ }^{2}$

World Bank defines Good Corporate Governance as "it is a collection of laws, regulations and rules that must be met to encourage the performance of company resources to work efficiently, resulting in long-term and sustainable economic value for shareholders as well as the surrounding community as a whole". ${ }^{3}$

The principle of sound banking requires the principle of healthy credit because they both influence each other. The principle of sound banking depends on the principles of healthy credit. So to make it happen, the role of bank supervision strongly support in the policies, procedures and guidelines for credit assessment, and test the consistency of implementation. It is possible to avoid the risk of lending, because the factors causing banking crisis caused by poor management and the quality of bank supervision is less effective. So the banking crisis caused by poor management and lack of effective bank supervision cannot be assigned to debtor to bear the loss in the form of increase in interest rates suddenly without the knowledge of debtor.

It is necessary to be observed that poor bank management is characterized by the presence of policies that allow banks to invest their funds in low-quality assets, taking excessive risks, and is unable to detect deterioration in asset quality and risk positions, and unable to handle it well. The indications are; internal control and internal audit are not working, not realistic valuation of assets included in the classification of credit quality, and not transparent. Because a bank is under poor management, bank supervision is in trouble. They can not be on time or late in detecting the problems faced by banks, so it's too late or not ready to take corrective or remedial measures.

Addressing this problem, it is required Prudential Regulation and Supervision Prudential in order that the health and stability of banking system is not disrupted. Prudential Regulation and Prudential Supervision are the concepts and techniques to control risks arising from bank so that it is expected to support the creation of safety and health of banking system. To assess for a

${ }^{2}$ I. Nyoman Tjager, dkk. (2003). Corporate Governance Tantangan dan Kesempatan Bagi Komunitas Bisnis Indonesia. Jakarta: PT. Prenhalindo. p.18.

${ }^{3}$ Hassel Nogi S. Tangkilisan. (2003). Mengelola Kredit Berbasis Good Corporate Governance, Yogyakarta: Balairung \& Co. p.12. 
healthy or unhealthy bank, it is used an approach called CAMEL, namely: Capital, to ensure the adequacy of capital and reserves, to bear the risks that may arise. Capital is a stronghold for bank; Asset, to ensure the quality of bank assets and the real value of the asset. And asset quality deterioration is the greatest source of bank capital erosion; Management, to ensure the quality and depth of the principle application of sound bank management, especially related to risk management. Competent and high integrity management are the spearhead of the defense at the risk of bank; Earning, to ensure that the efficiency and quality of bank earnings are true and accurate. Weaknesses in terms of real income is an indicator of the potential problems for banks; liquidity, to ensure the implementation of asset and liability management in determining and providing sufficient liquidity and minimizing the risk exposure that is sensitive to interest rate risk.

Basically the condition of banking system in the context and economic development depends largely on the principles and methods used in bank supervision in the form of: Regulation, The direct and indirect monitoring; Contacts and regular communication with bank; Acts of remedial and / or sanction application.

Furthermore, Good Corporate Governance (GCG) is a banking activity in order to avoid economic crisis because one of the crisis causes is low governance standards, both in public and corporate sectors of the economy.

The principles of Good Corporate Governance organized by OECD consists of five aspects:

1. Transparency, openness of information, in decision-making process and revealing material and relevant information about the company.

2. Accountability is the clarity of function, structure, systems and accountability of corporate organs so that the management of company can be effectively implemented.

3. Responsibility, company's responsibility, namely the compliance (obedient) in the management of company on sound corporate principles and applicable laws.

4. Independency, or independence, is a state where a company is managed in a professional manner without any conflict of interest that does not comply with existing regulations and the principles of healthy corporation.

5. Justice (equality and fairness) is a fair and equitable treatment in meeting stakeholders' rights arising under contracts and prevailing laws.

The enforcement of the Good Corporate Governance principles in banking organization should be applied, because banking case as the indicator is how weak the enforcement of good corporate governance in the management of state enterprises in Indonesia, so it can have a negative impact on the performance of the national economic recovery and the image of national banks.

The implementation of prudential banking principles and the principles of Good Corporate Governance (GCG) in banking activities can be a foundation in the making of bank credit Contract, so that the clause drafts is not an entrapment of the responsibility delegation that falls unilaterally to debtor but should be the responsibility of the parties bound by the contract. 


\section{B. Refunctionalization to the Contract Law Principles in Banking Standard Contract}

The definition of legal principles, as follows:4 "The legal principle as the basic thoughts and as the basis of a fundamental rule that becomes the foundation of the legal system"

The distinction of common law principle and special law princial, as described by Prof. Dr. Sudikno Mertokusumo, SH, as follows: ${ }^{5}$

"The common law principle is the principle of law relating to the whole field of law, such as the principle of Restitutio in integrum, the principle of lex posteriori detogat legi priori, the principle that physically looks right, for a while should be considered so until terminated (other) by the court.

The principle of a special law serves in a narrower field, as in the field of civil law, criminal law, and so on, which is often is a translation of the general legal principle, such as the principle of pacta sunt servanda, consensualism principle, the principle contained in Article 1977 BW, and the presumption of innocence. "

The principles contained in the Civil Code, as follows:

\section{The Principle of Freedom of Contract} Code;

The principle of freedom of contract is implied in Article 1338 of Civil

A contract can not be cancelled except by the contract of both parties, or for the reasons which is considered enough by the law for it.

A contract must be executed in goodwill.

Freedom of contract is one of the principles of contract law which is not independent from the other principles of contract law because the meaning can only be determined after we understand its position in integrated relationship with other principles of contract law, which as a whole is a pillar, pole, and the foundation of contract law.

The principle of freedom of contract in connection with the Home Ownership Credit Contract which is from the form as standardized contract then we may conclude that the characteristics of the Home Ownership Credit Contract are:

a. The content is determined only by creditors who are relatively in more powerful position than debtor;

b. Debtor does not participate in determining the content of the Contract;

c. It is driven by the requirement that debtor is forced to accept the Contract;

d. A written form;

e. It is prepared in advance in mass or individually.

The question here, whether the exoneration clause / standard contract as stipulated in the house ownership contract can meet the principle of freedom of contract?

${ }^{4}$ Dr. Khudzalifah Dimyati, S.H., M.Hum. (2004). Teorisasi Hukum Studi tentang Perkembangan Pemikiran Hukum di Indonesia 1945 - 1990. Cetakan Pertama, Surakarta: Muhammadiyah University Press. p.193-194

${ }^{5}$ Prof. Dr. Sudikno Mertokusumo, S.H. (1999). Mengenal Hukum Suatu Pengantar, Cetak Kedua, Yogyakarta: Liberty. p.36. 
The principle of freedom of contract includes five kinds of freedom:

a. freedom of the parties to close or not close the contract;

b. freedom to determine with whom the parties will close the contract;

c. freedom of the parties to determine the form of a contract;

d. freedom of the parties to determine the contents of the contract;

e. freedom of the parties to determine the way how to close the contract.

Faced with the type and form of standard contract as mentioned above, from 5 freedom of contract owned by debtor of housing, there are just two freedoms, that is: freedom to close or not close the contract and the freedom to determine with whom to close the contract. Meanwhile, three other freedoms can not be owned or realized by debtor of housing.

Though in this case it is related to the right of housing debtor to participate in a contract, it is the human rights recognized in any democratic society. This human right is the right objectively and naturally inherent in every human being and should be recognized, respected, protected, and guaranteed by law.

The characteristics contained in the House Ownership Credit Contract by excluding and limiting bank's obligation as creditor has positioned debtors and creditors not in balanced position. Monopoly position of bank as creditor has opened up broad opportunities for them to abuse their position. Bank only set up their rights but not the obligations, so that debtor is not given the freedom as the right to determine the form and content of the contract and not given the freedom to determine how to close the contract. It can be concluded that the House ownership credit contract is in contrary to the principle of freedom of contract.

\section{The Legal Binding Principle}

The legal binding principle as the law is explicitly mentioned in the same chapter with the principle of freedom of contract, namely: Article 1338 of Civil Code states that: All Contracts made legally are valid as a law for those who make it.

It means that all contracts made legally will bind as the law for the parties to the contract. Therefore, the parties to the contract must comply with the contract they made as to obey the law. To the parties who violate the terms of the contract, they may be subject to sanctions as well as a violation of the law.

The legal binding and freedom of contract principles are contained in the same chapter, Article 1338 of Civil Code. Then, according to the legal logic, it means:

1) The two legal principles are interconnected with each other and must not conflict with one another, so that;

2) A contract shall bind as a law for the parties in the contract if the principle of freedom of contract consisting five freedoms is met in the making of the contract.

It can be said that House Ownership Credit Contract cannot bind the parties in it because the Contract does not meet the principle of freedom of contract. 


\section{Consensualism Principle}

Consensualism principle is stated implicitly in Article 1320 of Civil Code that for a legal contract it is required four conditions:

1. Mutual Consent;

2. Capacity;

3. Certain subject matter;

4. A lawful cause.

However, later in Article 1321 of Civil Code, it states that:

No Contract is valid if the agreement is given because of an oversight, or obtained by coercion or fraud.

The definition of coercion under Article 1323 Civil Code are those that lead to a sensible mind is not free to make decisions, and raises fears of a real loss.

Based on field data, it was found the element of compulsion from housing debtor against a clause of interest rate rising suddenly, without any notice and a huge penalty clause that cause weakness, doubt or distress to the parties to close contracts, so that the behavior or decision of debtor change dependently for the advantage of the contract maker. This condition is in accordance with the conditions of coercion, as expressed in Article 1323 of Civil Code. It can be said that: because of the House Ownership Credit Contract as the banking standard contract contract does not meet Article 1321 and 1323 of Civil Code, the House Ownership Credit Contract does not meet Consensualism principle as contained in Article 1320 of Civil Code.

\section{Equality Principle}

This principle places parties in equal level, there is no difference. Each party bound in the contract shall see this equality and requires both parties to respect each other as human beings created by God.

To realize a just society, then economic globalization requires the implementation of universal principles such as the application of the protection to human rights.

Starting from human rights as the natural right of all people, it would require a reorientation of the House Ownership Credit Contract in providing opportunities for housing debtors to sit together in determining the content of credit contracts or specify the clauses of the credit contract.

\section{Balance Principle}

This principle requires both parties to meet and implement the contract. The principle of balance is a continuation of the equality principle. In this case, both bound parties of the contract are expected to carry out their duties in goodwill so that the state of burden division on both side are in a state of balance between the interests of both sides; Housing Debtor and Bank as creditor in the rights and obligations.

\section{Moral Principle}

This principle requires the parties to a contract are bound to have the motivation to perform legal acts based on morality (moral), as the call of conscience. 
Having a business requires ethics, namely the values and moral norms that apply to business practices. Regarding ethical values in business, it is expected and to be people wishes that moral values should be embraced and owned by the business, so that the businessmen run the business not to solely pursue profit regardless the signs of moral / ethics, but they will always uphold ethical values in business.

Law as the embodiment of values implies that its presence is to protect and promote the values upheld by the society. It is meant that law can also be seen as a figure of value. Thus, law is not a technical institution with empty or sterile moral so that law can not be accepted as law, unless it is based on morality.

Moral standards in business as mentioned above are overlooked by businessmen in the course of banking business, especially in the relationship of credit contract. Customer is frequently used as an object in the business and not as a subject in the business so that customer / debtor is not given a chance to sit together in the making of standard banking contract contained in the House Ownership Credit Contract (mortgage) in expressing their wishes and rights as a legal subject. To realize housing debtor's legal protection in banking standard contract, it is necessary to have a supervision system in the making.

\section{Equity Principle}

The principle of equity set out in Article 1339 of Civil Code, in which the notion of "equity" is the same as "goodwill". With the equity of Article 1339 does not have much meaning other than goodwill contained in Article 1338 section 3 , only the sense of goodwill is more than words to show an intention than the abstract word of equity. ${ }^{6}$

The purpose of "equity (billijkheid)" and "goodwill (geode trouw)" is an act in accordance with the bonafides by means of doing based on a good understanding, honest and straight, it is present in human soul.

The theory of goodwill / equity can be included as a supplement by the judge in finding the law in order to satisfy the sense of justice of the parties bound in a contract. This is due to the fact that gradually and surely, the contract forms used in the community have changed and developed. Originally, contract is conceived as the terms and conditions agreed by parties as a result of negotiations or negotiations between the parties who made it, but it will eventually be found in contract standard to have a sense of justice and equality before the law. This is due to standard contracts are designed, composed, duplicated and distributed unilaterally by one party, namely bank (as banking standard contracts in house ownership contract), while the other is the customer / debtor who can only accept or reject (take it or leave it ).

Based on the principle of equity and goodwill, The right limitation of housing debtor by bank as the creator of the contract through the efforts to widely open possible opportunities for the fulfillment of the creator's rights of the contract will not be realized. Furthermore, by realizing their duty as a legal subject bound in relation to the Credit Contract, bank will undoubtedly be able to run banking business based on the principle of equity and goodwill.

${ }^{6}$ Pitlo. Evolutie in het Privaatrcht. HD. p.59-61. 


\section{Legal Assurance Principle}

The contents of the Contract should provide legal assurance of the parties bound by the contract.

Businessmen and consumers obey the law and obtain justice in the administration of consumer protection, and the state ensure legal assurance.

The flexibility of various Contract Law Principles can ensure the freedom demanded by business in order to accommodate economic arguments to be enforced. Consensualism principle, the legal binding principle and the principle of freedom of contract are the main pillars supporting the building the Contract Law. These three principles are interrelated to one another, and non-fulfillment of one of the principles can be said that the contract is in contrary to the Contract Law which may result in cancellation of the Contract.

Furthermore how does the position of the Banking Standard Contract in Consensualism Principle? The agreement of parties, can clearly be seen from the signing of debtor as the proof of debtor's agreement in the contract so that it can be said that the banking standard contract has met the elements of a contract legality as stated in Article 1320 of Civil Code. However, it needs to be underlined that the principle of goodwill as the building foundation comprehensively, must be acknowledged to have an important role in the Contract Law. Because Article of Civil Code 1321 states that: "No Contract is valid if the agreement is given because of an oversight, or obtained by coercion or fraud".

Article 1323 of Civil Code further emphasizes that: the action that leads to a sensible mind is not free to make decisions, and raises fears of a real loss.

Referring to the above rules, of course, the Banking Standard Contract is questionable for the validity because it is clearly in practice that there are so many debtors feel a sense of distress, feelings that they are not free because they are faced to a position to accept or reject (take it or leave it), with no possibility to negotiate or bargain.

The aforementioned is important to notice concerning in making the banking standard contract, it is strongly influenced by the concrete circumstances in which the clauses of the contract are made for the sake of the life continuity of a bank that will inevitably be based on profit oriented. This shows the attitude interpreting goodwill in a tricky way by prioritizing the interests of bank without taking into account the interests of debtor at all. Therefore, it is clearly in the banking standard contract clauses consist of debtor's responsibility but not the responsibility of bank as a creditor.

As mentioned above, the freedom offered by the principle of freedom of contract, or the elements of agreement which is the legal contract elements, lead to ambiguous situations in which the principle of goodwill is almost ignored, although the editorial clearly stated in Article 1338 Section (3) state that a contract should be implemented in goodwill, so the implementation should consist goodwill element and inspire the whole stage of the process of contract, not just at the time of execution but also the pre-contract and the closing time of the contract.

\section{Ethical Value in Business}

Running a business takes ethics, namely: ${ }^{7}$

${ }^{7}$ Keraf. A. Sony. (1998). Etika Bisnis, Tuntutan dan Relevansinya. Yogyakarta: Kanisius. 
1. Businesses are not only aiming for profit but need to consider human values, that will not sacrifice the lives of many people, so that the community was concerned that the business is conducted in an ethical manner;

2. Business is carried out between one man and another man so that it requires ethics as a guide and orientation for the decisions, the activities and human behavior in a business relation to one another;

3. Business is currently done in a very tight competition, so the business that competes by regarding ethical norms in an increasingly professional business climate would likely win;

4. Legality and morality are related, but different from each other since an activity that is legally acceptable, not necessarily ethically acceptable;

5. Ethics should be distinguished from empirical science based on a symptom or the repeated fact and occurs everywhere would result in a scientific law which is universally applicable;

6. Special circumstances causing the exclusion of ethics can not be used as a reason to consider that the business is un ethics;

7. Protests happening everywhere show that there are still many people and community groups that want to run the business well and care for ethical norms.

It means that business can remain in its purpose for profit but it is necessary to have ethical values in business.

Due to the importance of ethics then there are some reasons to know: ${ }^{8}$

1. Decision making must consider ethics in which ethical concerns noble values and act in one's life related to the principles that become the foundation for the realization of the values in all forms and types of interactions and relationships among people;

2. Any form of cooperation by a group of people is based on the conventions, customs, and collective agreement so that the application of ethics in all aspects of life and life experiences need to be considered;

3. Ethics can be used as guidelines for behavior and means of control;

4. Ethics show intrinsic value of human life.

Based on the principle of goodwill and equity as regulated in Article 1338 Section (3) and Article 1339, contract has the motivation to perform legal acts based on morality (moral), as the call of conscience. It means that business requires ethics, that is the values and moral norms, applied to business practices so that the business does not solely pursue profit regardless the signs of moral / ethical, but always uphold ethical values in business.

The types of banking ethics that require attention in the Credit Contract are:

\section{Ethics in the Field of Public Trust}

One of bank activities a financial institution is to lend people who need it and considered feasible by bank to get it.

The credit worthiness can not be separated from the principle of $4 \mathrm{C}$, namely: Character; Capacity; Capital; Collateral.

\footnotetext{
${ }^{8}$ Keraf A. Sonny (1993). Etika Bisnis Membangun Citra Bisnis sebagai Profesi Luhur. Yogyakarta. p.47-48.
} 
Character issue is closely related to the willingness to fulfill obligations / promises to banks, especially to pay back the debt with the interest on time. Talking about trust, we highlight the character issues. Although the capacity and capital is owned by debtor, but he was not willing to pay his credit, it means the bank is injured. The term capacity is closely related to the ability of debtors to manage credits given by banks. The term capital is related to financial matters and the debtor's capital. Collateral concerns about the security which is a last safety to credits given.

After the assessment process of $4 \mathrm{C}$ has been met by debtor, then it is a problem, how can bank foster public trust in general or debtor in specific in the bank activities of lending?

Bank as a service provider should be trusted. Bank Program in distributing credit is really trusted not to harm the public in general or / debtor in specific.

If banking ethics in terms of public trust is associated with Credit Contract, any thing that became the major things in contract should be clear, for example: credit score, credit interest, penalties must be clear, precise and reliable

Any information provided by bank must be reliable and should not provide any information that contains a lie. Because it has been the banking provision that bank should be able to provide clear information to debtor in respect of lending, so the risk experienced by debtor and bank can be avoided or customer / debtor can feel safe and trust on bank products. ${ }^{9}$ Thus, it is the bank obligation to present reliable information about the issues related to the lending distributed by banks to avoid non-performing loan. The provision of information should start from the beginning of the credit contract until the credit completion, and even banks are required to provide information relating to risks that may arise during the ongoing credit contract. It is intended that at the beginning of the contract, the customer / debtor is aware of the contents and purpose of the credit contract. If the customer is lack of education, it is bank's service to educate debtor or give advice in order to achieve customer or debtor satisfaction in bank service in avoiding losses that will be experienced both by banks and debtors due to lack of debtor's knowledge.

\section{Banking Ethics in the Field of Creating Goodwill}

In order to implement public trust, bank as the financial institutions or Indonesian banker must meet various conditions; Believe in Almighty God, Faithful to the Pancasila, dignity, honest, Proficient / expert, Fair.

The requirements above are a part of morality that should be owned by Indonesian banker in the financial institutions. This moral is a norm, ethics as an ideal banker type in Indonesian society, so a good banker will not violate the banking ethics.

Ethics and morality can not be separated with goodwill because goodwill is the morality of the parties to the contract. If goodwill is associated with the Credit Contract, all things set up as a clause that should be fulfilled by both parties must be made in goodwill. In stronger position, bank should not have the power to make Credit Contract arbitrarily purely for the benefit of bank regardless the interests of debtor. Bank should have goodwill in making contract clause with balance of rights and obligations of both bank and customer / debtor.

${ }^{9}$ Pranasari, K., Adrianus Meliala. (1991). Praktek Pemberian Keterangan yang tidak Benar, Suatu Modus Penyimpangan Ekonomi. Jakarta: UI Press. p.53. 
This clause should not merely the rights of bank and the Obligations of Debtor, while debtor's rights and bank's obligation is not included. If it is not included, it is clear that bank appears to have no goodwill on customer / debtor and only pursue profit. In business ethics, bank as the business should not only aim to profit, but need to consider human values; otherwise they will sacrifice many people's lives.

\section{Banking Ethics in the Field of Profit Earning}

Profit earning is the ability of banks to earn for profit. Profit is very influential in the growth of banking business.

One of banking businesses in earning for profit is to set interest rates to the development of banking business itself. Frequently, bank interest setting is an absolute condition which is not negotiable and must be obeyed by debtor.

Bank in earning for profit ethically is very important because: ${ }^{10}$

It will give more trust to the owners to invest their capital by purchasing shares issued by a bank, if bank wanted to increase its capital;

Bank in continuous losses may not continue in business. Profit is used to increase working capital;

Not all profits is distributed to shareholders, partially it is set aside in capital reserves. The increase in capital reserves adds credibility (trust level) of people to bank;

If profit is considered not enough, then most likely bank's capital is not increased, even shareholders may sell their shares to be divested to other more profitable company;

Profit is bank leadership skills assessment, namely: Stay away of extortion attitude toward others; not do anything to harm public interest.

So, basically, business activities require ethics because business is not only aiming for profit, but it needs to consider human values in order not to sacrifice many people's lives. It means that, despite the special circumstances mentioned above which lead to the exclusion of ethics, it can not be used as a reason to consider unethical business. Although banking activities might get the legality of profit oriented, it will be in contrast to morality as a legal activity is not always ethically acceptable. However, along with the development of responsive law, law must be seen as the embodiment of meaningful values, its presence is to protect and promote the values upheld by society. Therefore, law can be seen as a figure of value because law is not a technical institution with empty moral or sterile. It can be said, law can not be accepted as law, unless it is based on morality.

\section{Act No. 8, 1999 on Consumer Protection}

Act No. 8, 1999 on Consumer Protection was passed through a long struggle of consumer movement taking almost three decades. Indonesia's consumer protection movement that was driven by the Indonesian Consumers Foundation (YLKI) since 1973 has paid off with the passing of Act No. 8, 1999 on Consumer Protection, which is expected to provide the rights and interests of customers. Their helplessness in harmful trading system has placed consumer as a community group that must be defended.

${ }^{10}$ O.P. Simorangkir. (2003). Etika: Bisnis, Jabatan dan Perbankan. Rineka Cipta. p.164. 
In relation with the existence of Banking Standard Contract as a standard contract that has provided an unbalanced position between bank and debtor, basically the Consumer Protection Act does not prohibit the business to make a standard contract containing standard clause, as long as it should be noticed, the prohibition in the contract-making standard, as stated in Article 18 section (1) of Consumer Protection Act on the clauses providing consumer's submission to new rules, an additional, secondary and / or alteration made up unilaterally by businesses in the period of consumer utilizing the services they buy. Therefore, the clauses in the banking standard contract on interest rate increase will changed at any time without prior approval by debtor, its existence needs to be reviewed because this clause is clearly contrary to article 18 section (1), that the business shall be prohibited to include a clause stating the submission of consumers to new rules, an additional, secondary and / or alteration made up unilaterally by businesses in the period of consumer use services they buy.

Actually, the Consumer Protection Act has set the limits to be an important note for Banking Standards Contract as a standard contract, which is about the principle of Justice, Equality Principle and the principle of balance as provided in Article 2. From Article 2, Consumer Rights was born as set forth in Article 4, that the consumer has the right to be heard; entitled to get the correct and clear information, and to get the right, fair and not discriminatory treatment.

The implementation of justice, equity, and balance principle in Banking Standard Contract must reflect a balanced position between bank and debtor. In addition, the form of the equality principle will appear if bank pays attention to the right of debtor to be heard, to get the correct and clear information, and is entitled to get the right, fair and not discriminatory treatment.

It means that, since the making of Banking Standard Contract, Consumer Protection Act has set that the position of bank and debtor should be balanced. The balance will be there if debtor receives similar position to determine the content of contract so that banking standard contract would contains clearly the rights and obligations of bank and debtor.

\section{E. The Enforcement of Human Righ Principle}

The enforcement of Human Rights can be the foundation on Banking Standards Contract, namely:

1. Article 19 of Declaration of Human Rights states that:

"Every person has the right to freedom of opinion and expression: this right includes freedom to have their opinions by not getting interference and to seek, receive and convey descriptions and opinions in any way and with no boundaries ".

2. Covenant on Civil Political Rights, Article 19 states: "Everyone has the right to have opinions without interference and everyone is entitled to an opinion; this right includes freedom to seek, receive and convey information and ideas of all kinds, regardless of restrictions, either orally, written or printed, in the form of art, or through other media by choice ".

3. Article $28 \mathrm{~F}$ of the Constitution of 1945 (UUD 1945) asserts that Everyone has the right to communicate and obtain information to develop their personal and social environment, and the right to seek, obtain, possess, store, process and convey information by using all available channels. 
The stipulations as mentioned above is a legal consequence so that whatever the reason is still in Banking Standards Contract, the principle of human rights must be upheld concerning the increasingly widespread use of banking clauses that do not meet the elements of legal justice and balance which are complained by many debtors.

\section{F. The Abuse of Circumstances Doctrine (Misbruik van Omstandig- heden)}

Completing the view of Van Dunne, J. Satrio reveals the characteristics of the abuse of circumstances: ${ }^{11}$

Huge losses for one of the parties.

The Contract contains an unequal relationship in mutual obligations among the parties (the imbalanced achievement).

There is the abuse of circumstance element when the weaker party is in a position which depends on the ruling party. This can be seen in the presence of monopolistic relationships, in which the other party has no choice, other than accept the terms proposed by the monopolist.

As we know that the contract made as the basis of business activities has the basic rules in Indonesian Civil Law Code of Book III, it is the Dutch heritage which still applies today. Ironically, the Dutch Contract Law has developed and changed with the inclusion of the abuse of circumstance doctrine (van Misbruik Omstandigheden), but the Contract Law in Indonesia is still retained by the Civil Code (BW) which has been worn, the results of Dutch heritage, but the demands of economic actors requires the availability of the underlying principles of contract law buildings in order to accommodate or facilitate the accelerated development of banking standard contract.

The application of the abuse of circumstance doctrine is an attempt to anticipate the arbitrariness in the making of standard terms, so that through the implementation of the abuse of circumstance substance, it may limit the application of standard requirements. The application restrictions of the standard requirements are intended to avoid the occurrence of an arbitrary treatment of bank as the maker of the contract. Without limiting the application of standard requirement may cause the opportunity abuse by banks having economic advantages. Consciously or not, this situation has created a monopolistic relationship in which the other party has no choice, other than accept the terms proposed by the monopoly holder.

Increasingly widespread banking standard contract complained by many debtors, it is actually a sign that it is time to support the idea of adopting the abuse of circumstance doctrine (misbruik van omstandigheden) in Indonesia's legal system. It means that there is a basis of authority for judges to ignore the implementation of the terms of which a contract is made in unfair and arbitrary way, and it should be used as the basis for new development for the successful efforts of a contract cancellation.

\footnotetext{
${ }^{11}$ J. Satrio. (1995). Hukum Perikatan, Perikatan yang Lahir dari Perjanjian. Jakarta: PT Grasindo.
} P.230-232. 


\section{Conclusion}

Due to the demands of efficiency, utilization of banking standard Contract as standard contract in the practice of business transactions would be inevitable. Standard contract as the implementation and a reflection of the principle of freedom of contract has almost become the needs that can not be avoided in this modern era of trade. Therefore, this should be addressed by legal persons with a pattern of thinking on how to use the standard contract optimally in order to accommodate the balance of rights and obligations of the parties for the realization of a sound business transaction. Lawyers should not be negligent so as to make a carelessness that can be harmful. Therefore, the discourse around the renewal of banking standard contracts as standard contracts, the role of scientists with their various analysis, contribute significantly considering the renewal efforts to develop the principles of contract law in Indonesia should be done by the government but it has not been addressed yet. Therefore, one of the respectable ways is by as often as possible taking the time to open a dialogue between practitioners and academics and other parties concerned in order to create the assembly of the contract term made in detail to explain the content of the parties' rights and obligations so that the authority of each party is transparent. It is intended to contribute the judges in the judicial field to tackle the excesses of banking standard contract. The condition of legal gaps in the banking standard contract should be terminated as soon as possible in order that the legal developments in the real sense really come up to the expectations of society. The judges are supposed to be back to school as soon as possible to gain knowledge on higher strata, so their knowledge that had been chained up by routines so far will be able to be reactualized in line with the existing developments.

\section{Bibliography}

\section{Books}

Keraf. A. Sony. (1993). Etika Bisnis, Membangun Citra Bisnis sebagai Profesi Luhur. Yogyakarta. Kanisius.

(1998). Etika Bisnis, Tuntutan dan Relevansinya. Yogyakarta:

Khudzalifah Dim

Pem Dimyati. (2004). Teorisasi Hukum Studi tentang Perkembangan

Pemikiran Hukum di Indonesia 1945 - 1990. Cetakan Pertama, Surakarta:

Muhammadiyah University Press.

Pitlo. Evolutie in het Privaatrcht. HD.

Pranasari, K., Adrianus Meliala. (1991). Praktek Pemberian Keterangan yang tidak Benar, Suatu Modus Penyimpangan Ekonomi. Jakarta: UI Press.

Rusado Ruslan. (1995). Seri Manajemen Public Relation; Aspek-aspek Hukum dan Etika dalam Kreatifitas Public Relation dan Kehumasan. Jakarta: Ghalia Indonesia.

Satrio, J. (1995). Hukum Perikatan, Perikatan yang Lahir dari Perjanjian. Jakarta: Penerbit PT Grasindo.

Simorangkir O.P. (2003). Etika: Bisnis, Jabatan dan Perbankan. Rineka Cipta. 
Sudikno Mertokusumo. (1999). Mengenal Hukum Suatu Pengantar. Cetak Kedua, Yogyakarta: Liberty.

Tangkilisan Hassel Nogi S. (2003). Mengelola Kredit Berbasis Good Corporate Governance. Yogyakarta: Balairung \& Co Yogyakarta.

Tjager Nyoman I., dkk. (2003). Corporate Governance Tantangan dan Kesempatan Bagi Komunitas Bisnis Indonesia. Jakarta: PT. Prenhalindo. 